\title{
Filariasis in the new millennium
}

\author{
R.H.H. Nelwan
}

\begin{abstract}
Abstrak
Pengendalian filariasis di Indonesia yang bertujuan mencapai microfilaria rate di bawah $1 \%$ di daerah endemik sampai terjadinya krisis moneter 3 tahun yang lalu selalu menunjukkan kemajuan yang cukup mengesankan dari tahun ke tahun. Ternyata bahwa saat ini di berbagai wilayah yang untuk jangka waktu yang lama sudah bebas dari filariasis mulai lagi pelaporan kasus kaki gajah. Keadaan ini mungkin tidak lepas dari pergolakan multidimensi yang telah mengakibatkan pengungsian penderita dari daerah endemik ke wilayah-wilayah aman y'ang non-endemik untuk filariasis. Makalah ini bertujuan untuk mengingatkan kita akan cara penyebaran filaria dan berbagai gejala klinis yang berhubungan erat dengannya serta mengenai penatalaksanaannya masa kini. Juga akan dibahas kemajuan mutakhir yang telah dicapai terutama di bidang diagnostik dan pengobatan penduduk secara massal, terfokus dan bebas efek samping yang pada saat ini sangat menonjol. Tulisan ini juga dimaksudkan sebagai pengantar mengenai peluang pemberantasan filariasis melalui apa yang dikenal sebagai suatu aliansi penuntasan global dengan mengikutsertakan berbagai pihak antara lain farmasi multinasional yang telah mengikrarkan penyediaan obat secara gratis sesuai kebutuhan dari organisasi kesehatan dunia WHO. Badan ini memegang kendali pemberantasannya melalui Program Tropical Disease Research (TDR) Task Force on Filariasis Intervention Research yang bersama TDR Product Development yang mengatur pengembangan terapi merupakan bagian dari program WHO untuk eliminasi total filariasis dari muka bumi dunia. (Med J Indones 2001; 10: 191-6)
\end{abstract}

\begin{abstract}
The Indonesian national filariasis eradication program in its pursuit in obtaining microfilarial rates below $1 \%$ in filariasis endemic locations was on its right track until the monetary crisis started 3 years ago. This crisis which is not over yet at present is complicated by unstable public safety causing population shifts where people from filaria endemic locations seek refuge in non-endemic areas. This updated review will hopefully serve as a timely reminder to our physicians and health workers especially on the mode of filarial transmission as well as on its clinical presentations and presently accepted ways of management. This paper also will serve as an introduction into the present breakthroughs in this new millenium as noted in the field of diagnostics and simplified mass treatment schedules making it possible for the elinination of lymphatic filariasis as a public health problem. A global alliance under the guidance of the World Health Organization with support of the multinational pharmaceutical companies for providing free expensive medication as needed. The WHO also cooperates closely with the Tropical Diseases Research task forces of Filariasis Intervention Research and of Product Development, that in the end will provide the means to eradicate this disease for once and forever from the face of the earth. (Med J Indones 2001; 10: 191-6)
\end{abstract}

Keywords: Lymphatic filariasis, filarial lifecycle, global alliance, historical milestones

Infection with filarial nematodes are the main cause of lymphatic filariasis and all its consequences. Near the end of the XXth century WHO estimation of cases stood at 120 million with one third of them belonging to the disabled category. These cases are mostly spread over the tropical belt on both sides of the equator with an approximate of 1.2 billion people at risk. ${ }^{1}$ The present state of its epidemiology, clinical

Division of Tropical and Infectious Diseases, Department of Internal Medicine, Faculty of Medicine University of Indonesia, Jakarta, Indonesia

Presented at the $2^{\text {nd }}$ Maastricht Travel and Tropical Medicine Symposium September 2000 in Maastricht, The Netherlands. features, diagnosis, treatment and prevention will be overviewed in this article.

\section{EPIDEMIOLOGY}

The main cause of filarial infections are Wuchereria bancrofti and Brugia malayi with an isolated species found only in Eastern part of Indonesia and Timor lorosae known as Brugia timori. Microscopically the microfilariae ( $\mathrm{mf}$ ) of these species can be differentiated according to their respective morphology. Their distribution are of world wide spread between latitudes $40^{\circ}$ North and $30^{\circ}$ South. While W.bancrofti may be found mostly in Africa, Asia and the Pacific 
Islands, it is also present focally in the Eastern Mediterranean and in Latin America. B. malayi is spread throughout the South East Asian region with some small foci in other parts of Asia, in contrast with B.timori that is found only in the islands of Southeastern Indonesia formerly known as the Lesser Sunda Islands. ${ }^{2,3}$ A historical account about investigators and reports closely connected with lymphatic filariasis is depicted in table 1 .

Table 1. Lymphatic filariasis: historical mulestones

\begin{tabular}{|c|c|c|c|}
\hline Year & $\begin{array}{l}\text { Author/ } \\
\text { Investigator }\end{array}$ & Description & Location \\
\hline $\begin{array}{l}70 \\
\mathrm{AD}\end{array}$ & Sushruta & Slipada disease & India \\
\hline 900 & Abecenna & Swollen extremities & Egypt \\
\hline 1863 & J.N. Demarquay & Hydrocele fluid & Cuban patient \\
\hline 1868 & O.E.H. Wucherer & $\begin{array}{l}\text { Worm in chylous } \\
\text { urine }\end{array}$ & Brazil \\
\hline 1877 & J. Bancroft & Adult filaria & Australia \\
\hline 1878 & P. Manson & $\begin{array}{l}\text { Mosquitoes as } \\
\text { vector }\end{array}$ & China \\
\hline 1927 & Lichtenstein & New species & Sulawesi \\
\hline 1927 & S.L. Brug & W. malayi* & Sumatera \\
\hline 1940 & $\begin{array}{l}\text { SS Rao/ } \\
\text { PA Maplestone }\end{array}$ & W. malayi Af.* & India " \\
\hline 1965 & $\begin{array}{l}\text { H.L. David/ } \\
\text { SFB Edeson }\end{array}$ & New species & Timor lorosae \\
\hline 1966 & Sri Oemijati & Mf. Timori & Timor \\
\hline 1976 & DT Dennis et al & B. timori & Timor \\
\hline 1978 & F. Partono et al & B. timori & Flores \\
\hline
\end{tabular}

* Renamed as Brugia malayi in $1958 \quad$ Af = adult filaria Mf = microfilaria
The host of all the three types of filarial infection is man except for the sub periodic form of B.malayi that may also infect monkeys, domestic cats and forest carnivores. Infection may be acquired at an early age, however there is a low rate of microfilaraemia in early childhood, a fairly rapid rise between the age of 5 to 20 years reaching a certain plateau thereafter. As densities of Mf may rise and fall in individuals it is not a useful indication for infection intensity or disease individually. In the community, however, the collective Mf rate and log median microfilarial density reflect the intensity of transmission and disease impact. From various studies males often have higher rates of microfilaraemia and clinical signs. The infection is also more prevalent in the lower socio-economic groups due to inadequate protection from mosquitoes and unhygienic conditions favorable to breeding of vectors, immigrant populations especially adults may show more rapidly developing and severe disease. ${ }^{4}$

Many different species of mosquitoes serve as vector including Anopheles, Culex and Aedes for bancroftian filariasis, Mansonia species, Anopheles and Aedes for brugian filariasis and Anopheles barbirostris for timorian filariasis. ${ }^{5}$

Urban transmission by mosquitoes is very low requiring numerous bites (16.000) of infectious mosquitoes for one new patent infection in man. Contrary to this only 200 bites of infectious mosquitoes a year per person will maintain transmission at endemic levels.

Vector biting intensity parallels age prevalence of infection. ${ }^{6}$ A diagrammatic flow chart of the lifecycle of lymphatic filarial parasites is shown in figure 1 .

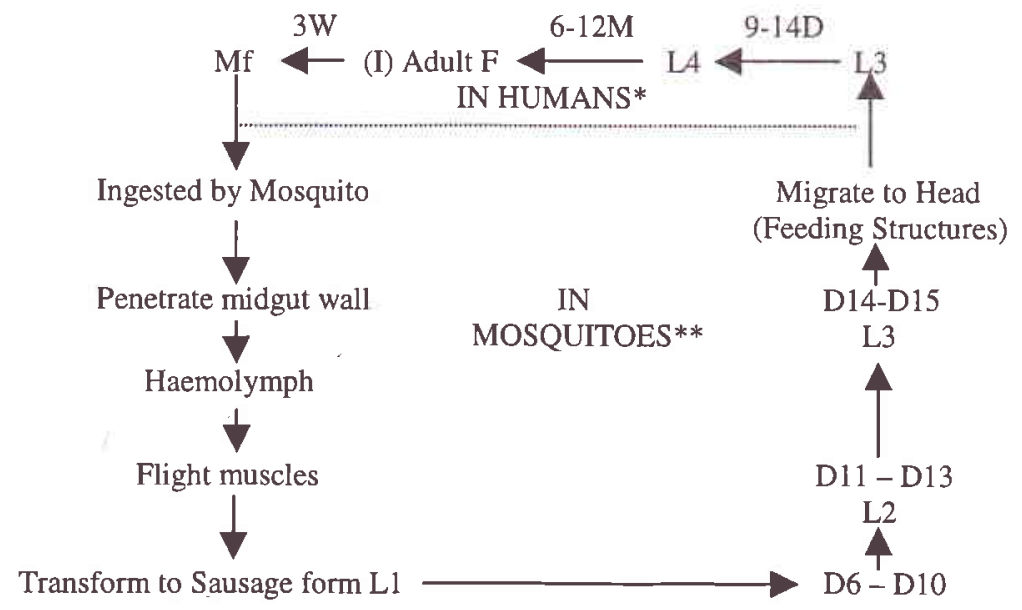

Figure 1. Life cycle of lymphatic dwelling filariae

$I=$ Insemination $\quad F=$ filarial worm $\quad L=$ larval stage $\quad M=$ months $\quad W=$ weeks $\quad D=$ day

* Brugia spp mature on an average of 3 months ** Brugia spp molt development average 10 days 


\section{CLINICAL PICTURE}

Infection with filarial species may manifest itself after an incubation period from $31 / 2$ to 12 months. Lymphatic filariasis is marked by an acute attack of localized pain, tenderness, swelling and erythema. This kind of attack may vary from only a few during a whole lifetime to more than one attack monthly and are most frequently experienced by adolescents and young adults. Filarial adenolymphangitis is mainly caused by the adult worms. Living microfilariae do not generally produce any lesions. ${ }^{7}$ In bancroftian filariasis recurrent attacks of fever with lymphadenitis are less frequent seen than in brugian filariasis. In brugian filariasis the affected lymphnodes are mostly situated in the inguinal and axillary regions. ${ }^{8}$ In bancroftian filariasis besides inguinal and axillary regions also include the epitrochlear regions and the lymphatic system of the male genitalia. Orchitis, funiculitis and epididymitis last for 3-5 days but may persist for 1 to 2 weeks and may recur. Whenever repeated acute inflammatory attacks occur chronic lymphedema and hydrocele may appear late in the second decade, with peak incidence in the third and fourth decade. Areas with intense transmission may cause development of clinical severity at an early age. Besides this one should become alert when edema persist for a period of more than 6 months as elephiantiasis could occur within 1-2 years in nonindigenous persons moving to endemic areas. ${ }^{8} \mathrm{~A}$ diagram on possible clinical manifestation in filarial infection is shown in figure 2. Minimal damage in the kidney due to the high concentration of microfilariae during the day time in the microvasculature of the deep lying internal organs may cause either microscopic haematuria, microscopic proteinuria or both. The majority of Mf however is predominantely concentrated in the lungs and may cause eosinophilia. Most of the elephantiasis new cases are recorded between the age of 25 and 40. Progression may cause the soft and pitting edema transfer into a non-pitting solid firmness due to hypertrophy and fibrous hyperplasia of the skin and subcutaneous tissues.

Bancroftian filariasis involves the whole of the arms or legs while brugian filariasis involves mostly parts below the elbow or knee.

The swelling may reach great deformity causing incapacitation and psychosocial problems. This condition may either develop insidious without recurrent episodes of acute symptoms. Beside the legs, scrotum and arms, also the labia, penis or breast may be involved and these conditions hold true mainly for bancroftian filariasis. ${ }^{9}$

Two other clinical conditions associated with filarial infection include the passage of chylous urine due to rupture of the abdominal lymphatics into the urinary tract that so far is also only limited to bancroftian filariasis $^{10}$ and the tropical pulmonary eosinophilia syndrome marked by paroxysmal coughs without sputum production responding rapidly to treatment with diethylcarbamazine. ${ }^{11}$

\section{ADULT WORMS}

- Tropical pulmonary
Eosinophilia Syndr.

Figure 2. Clinical manifestations of lymphatic dwelling filariae 


\section{DIAGNOSIS}

Present day diagnostic techniques will be doing well in the new millenium to come and is not limited only to examination of the parasites in the blood or by quantitative blood count ( $\mathrm{QBC}$ ) systems for quicker results or by concentration techniques and usage of membrane filters which is perhaps the best direct way to show the microfilaria in peripheral night blood. ${ }^{12-14}$ In certain situations the diethylcarbamazine (DEC) provocative test of $50-100 \mathrm{~g}$ DEC may cause sequestered microfilariae to appear in the peripheral blood 15 to 90 minutes later. ${ }^{15,16}$ Certain contraindication to its use have to be observed. Adult filaria may be diagnosed from surgically removed material or by ultrasonographic examination where the motile adult within the dilated lymphatics have a distinctive pattern of movement described as the "Filaria Dance Sign". 17

Besides the detection of the parasite itself, its products or antigens and even its DNA may be targeted for diagnosis. Circulating filarial antigen can be detected by the capture Elisa test. These positive test should be interpreted as evidence for active infection. These tests are limited only for the diagnosis of bancroftian filariasis at the present moment. Two independently characterized antibodies $\mathrm{AD}_{12}$ and $\mathrm{Og}_{4} \mathrm{C}_{3}$ that recognize protein moieties of the prominent excretory-secretory product phosphoryl choline from filarial parasites were developed as monoclonal antifilarial antibodies and are at present commercially available. In microfilaraemic persons its sensitivity approach $100 \%$. The assay also has a high specificity (99-100\%). Field performance of these test as reported by Simonsen and Dunyo showed high degree of positive/negative response similarity. Bancroftian filariasis may be detected by polymerase chain reaction based on the highly repeated deoxyribonucleic acid (DNA) found in the parasites. ${ }^{19}$ Besides from blood samples the DNA was also possible to be detected from patient's saliva and urine. ${ }^{19,20}$ Detection of circulating DNA in day blood $(11.00-14.00)$ was shown in microfilaraemic individuals and in $91.1 \%$ of amicrofilaraemic subjects. ${ }^{21}$ Serodiagnosis at present when negative have a meaningful interpretation of exclusion of both past and present infection. A serological test for $B$. malayi against $\mathrm{IgG}_{4}$ antibodies is at present available but not commercially produced yet. The usage of these new test as described above has to meet certain requirements when applied to actual patients. For the antigen detection assays post treatment assessment should be undertaken beyond 6 months after completion of treatment.

Assays based on $\operatorname{IgG}_{4}$ subclass antibodies with sensitivity ranging from $90-95 \%$ are less sensitive than parasitological diagnosis. They also may cross react with other filarial infection that are co-endemic which also limits its specificity.

The PCR based diagnosis may have greater sensitivity compared to the parasitological methods. This technique is also useful for detecting cryptic infections (amicrofilaraemia) in some subjects.

\section{TREATMENT}

Treatment may be focused towards the individual who is very likely to comply or to the community where only a portion may be suffering so that reluctancy towards taking medication with possible adverse effects may become a problem in mass treatment programs.

The different forms of lymphatic filariasis may require management according to their respective clinical presentations. The recommended treatment dosage of DEC according to the WHO is $6 \mathrm{mg} / \mathrm{kgBW} /$ day for 12 days for bancroftian filariasis given a total of 72 $\mathrm{mg} / \mathrm{kg}$ of DEC. However present available studies indicate that even a single dose treatment with $6 \mathrm{mg} / \mathrm{kg}$ of DEC on a long term basis has comparable macrofilaricidal and longterm microfilarial suppression effects. For those who still remain infected this dosage can be repeated every 6 months. For brugian filariasis the Indonesian dosage schedule is limited to 10 days with $5 \mathrm{mg} \mathrm{DEC} / \mathrm{kgBW} /$ day. Besides, because of possible severe side effects even lower dosages for longer duration of treatment have been advocated.

DEC fortified salts $(0,2-0,4 \%)$ have also been recommended by the WHO for one year usage for control of filariasis. Local studies with $0,2 \%$ DEC for 2 months and $0,1 \%$ for 4 months were evaluated in Indonesia giving indeed reduced $\mathrm{mf}$ rates by $75 \%$ compared to $14 \%$ in the control area after one year. ${ }^{22}$ Local studies have shown that adverse reactions to DEC could be correlated with pre-treatment high levels of circulating microfilariae. ${ }^{23}$ Other local studies as part of the WHO multicentered effort to test new antifilarial compounds used the non-human primate model Wuchereria kalimantani - Presbytis cristata for drug efficacy screening. ${ }^{24}$ The compound 
CGI 18041 a benzothiazol isothiocyanate N-methyl piperazine was evaluated and found to be both macro and microfilaricidal at 50 and $100 \mathrm{mg} / \mathrm{kg}$ in a single dose. ${ }^{25}$ Circulating filarial antigens (CFA) changes were also determined and described after treatment with various dosages of CGI 18041 concluding that there was an initial rise followed by deep fall and then a second rise of CFA. ${ }^{26}$ Other drugs that are presently available in the clinic include ivermectin 200-400 $\mu \mathrm{g} / \mathrm{kg}^{27}$ especially to be used in areas endemic also for loiasis and onchocerciasis and also albendazole 400 $\mu \mathrm{g} / \mathrm{kg}{ }^{28}$ A drug for the future may be moxidectin that is presently used in veterinary medicine but is now ready for evaluation in humans. ${ }^{29}$

Supportive treatment are needed for acute attacks such as analgesics and sometimes, antibiotics, for lymphedema: proper skin care, hygiene, elevation and compressive bandages may be applied and for chyluria a low fat high protein diet may hasten improvements. Surgery may be needed in hydrocele and chylocele situation and also in advanced cases of elephantiasis.

\section{PREVENTION AND CONTROL}

A strategy for eliminating lymphatic filariasis has to be adopted nationally. Firstly the infected individuals should become the main target for control of infection through proper treatment and monitoring on a long term basis. Parasite control in patients will contribute to interruption of community infections. Secondly, transmission of infections in the community should be identified and halted. These communities should be surveyed by field studies and community wide mass treatment campaigns should be undertaken to treat the entire population.

The Indonesian Filariasis Eradication Program that kicked off in 1970 made substantial progress (table 2) bringing down the previous high average $\mathrm{mf}$ rate of $21.6 \%$ to one seventh (3.1\%) just before the economic crisis. ${ }^{30}$ Cases are on the increase presently. Advances attained especially during the last decade of the past millennium favors success for elimination of lymphatic filariasis in the new millennium with the detailed understanding of usage of presently available antifilarial drugs, very simplified mass treatment schedules and diagnostic monitoring tools that are very accurate, easier to handle and are becoming more widely available at the moment. The global alliance for eradication of filariasis will provide free drugs by the multinational pharmaceutical companies especially the producers of expensive albendazole and ivermectin. Diagnostic ICT cards for antigen detection at cost price will be made available by AMRAD. This alliance also consists of non-govermental development organizations besides established international organizations supported by academic institutions and private industries. On top of it filaria support centers throughout the world will be established for reference and in depth study under guidance of the WHO. The global elimination of lymphatic filariasis as a public health problem was announced by WHO in 1997 with the principal strategy for interrupting parasite transmission by annual mass treatment. A historic meeting in early 2000 (London) brings renewed hope to control this disease in the new millennium in the millions of filarial infected person as well as accomplish complete prevention for developing the disease in the huge population that is at risk especially children spread over the 73 endemic countries in whom an estimated one million new cases each year occur. ${ }^{31}$

Table 2. Indonesian filariasis control program

\begin{tabular}{|c|c|}
\hline Main Objective & $\begin{array}{l}: \text { To obtain a microfilarial (mf) rate of less } \\
\text { than } 1 \% \text { for all endemic locations }\end{array}$ \\
\hline 1957 & : Mf rate in Jakarta State Capital (12-23\%) \\
\hline 1970 & $\begin{array}{l}\text { National Mf rate Average } 21,6 \%(0-37,6 \%) \\
\text { Start of Filariasis Eradication Program (FEP) }\end{array}$ \\
\hline 1990 & : National Mf rate Average $4,3 \%(0-23,8 \%)$ \\
\hline 1997 & $\begin{array}{l}\text { National Mf rate Average 3,1\% (0,5-17,9\%) } \\
\text { Just before the economic crisis }\end{array}$ \\
\hline 2000 & $\begin{array}{l}\text { Increase in number of positive reporting } \\
\text { provinces } \\
\text { Three fold increase of filarial case } \\
\text { (Mid '00 vs ' } 98 \text { ) }\end{array}$ \\
\hline
\end{tabular}

\section{REFERENCES}

1. World Health Organization. The Health Report. Fighting Diseases Fostering Developments. WHO-Geneva-1996.

2. Michael E, Bundy DAP. Global mapping of lymphatic filariasis. Parasitol Today 1997;13:472 - 6 .

3. Oemijati S, Liem KT. Description of microfilaria timori. $10^{\text {th }}$ Pacific Science Congress, Tokyo. 1966.

4. World Health Organization. Lymphatic Filariasis. The Diseases and its Control WHO-Geneva.1992

5. Strickland GT. Hunter's Tropical Medicine $6^{\text {th }}$ ed W.B Saunders 1984:653.

6. Michael E, Bundy DAP. Herd Immunity to filarial infection is a function of vector biting rate. Proc $\mathrm{R}$ Soc Lon B 1998; 265 :855-60. 
7. Shenoy RK, Sandhya K, Suma TK, Kusmaraswami V. A preliminary study of filarisis related acute adenolymphangitis SE Asian J Trop Med Publ Hlth 1995; 26:301-5.

8. Partono F. The spectrum of disease in lymphatic filariasis CIBA Found Symp 1987;127:15-31.

9. Sri Tinon RK. Lymphangiographical importance in human bancroftian filarial elephantiasis. Maj. Radiol Indon 1982; 6:17-29.

10. Klousia JW, McClennan BL, Semerjian HS. Chyluria: A brief literature review. J Urol 1977;114:393-4.

11. Ottesen EA, Nutman TB. Tropical Pulmonary Eosinophilia Annu Rey Med 1992;43: 417-24.

12. Bawden M, Slaten D, Malone J. QBC: rapid filaria diagnosis from blood. Trans R Soc Trop Med Hyg 1994; 88:66.

13. Knott J. A method for making microfilarial surveys on day blood. Trans R Soc Trop Med Hyg 1939;33:191.

14. Bell D. Membrane Filters and Microfilariae: A new diagnostic technique. Ann Trop Med Parasitol 1967;61: $220-3$.

15. Katamine D, Tamura $Y$, Moriguchi $Y$. An experiment to demonstrate microfilaria of W. bancrofti in the day time, Nagasaki I Zosski 1952;27 : 232-4.

16. Partono F, Cross JH, Borahina, Clarke MD, Oemijati S. Observation on the diurnal diagnosis of filaria after a single dose of hetrazan SE Asian J Trop Med Public Hlth 1972; 3:366-70.

17. Amaral F, Dreyer G, Figueredo SJ, Noroes J, Cavalcanti A, Samico SC et al . Live adult worms detected by USG in human bancroftian filariasis. Am J Trop Med Hyg 1994; 50:753-7.

18. Simonsen PE, Dunyo SK. Comparative evaluation of three new tools for diagnosis of bancroftian filariasis based on detection of specific antigens. Trans R Soc Trop Med Hyg $1999 ; 93: 278-82$.

19. Zhong M, McCarthy J, Bierwert L, Lizotte-Waniewski M, Chanteau S, Nutman TB et al. A PCR assay for detection of the parasite Wuchereria bancrofti in human blood samples. Am J Trop Med Hyg 1996;54:357-63.

20. Abbasi I, Hamburger J, Githure J, Ochola J, Agure R, Koech DK et.al. Detection of W. bancrofti DNA in patients sputum by the PRC. Trans R Soc Trop Med Hyg 1996; 90: 531-2.
21. Lucena WA, Dhalia R, Abath FGC, Nicolas L, Regis LN, Furtado AF. Diagnosis of W.bancrofti infection by PRC using urine and day blood samples from amicrofilaraemic patients. Trans R Soc Trop Med Hyg 1998; 92:290-3.

22. Marwoto DA, Darwis F, Sulaksono SE, Ompusunggu S, Liefwarni, Suparmo K. DEC-Salt for controlling Brugia malayi in South Kalimantan. J Indon Med Assoc 1997;47:248-52 (In Indonesian)

23. Haarbrink M, Terhell AJ, Abadi GK, Mitsui Y, Yazdanbakhsh M. Adverse reactions following DEC intake in "endemic normals", microfilaraemics and elephatiasis patients. Trans R Soc Trop Med Hyg 1999; 93:91-6.

24. Purnomo and Bintari R. Wurchereria kalimantani infected Presbytes Cristata : a primate model for drug trials in lymphatic filariasis. Med J Indones 1995; 4(2) : 84-6.

25. Supali T, Bintari R, Wibowo H, Ekarina R, Kurniawan A Wardhani ES et al. Treatment of Wuchereria kalimantani infection in Presbytis cristata with a single dose of CGI 18041. Med J Indones 1997;6(1):11-4.

26. Poerwaningsih N. Dynamics of Brugia malayi circulating antigen in experimental infection and after chemotherapy (Thesis) Institute of Medical Research Kuala Lumpur, Malaysia, 1996

27. Eberhard ML, Hightower AW, McNeeley DF and Lammie PJ.Long-term suppression of microfilaria following ivermectin treatment. Trans R Soc Trop Med Hyg 1992; 86:287-8.

28. Jayakody RL, DeSilva CSS and Weera Singhe WI. Treatment of bancroftian filariasis with albendazole, Evaluation of efficacy and adverse reactions. Trop Biomed 1993;10:19-24.

29. TDR news. A suitable microfilariacide. An UNDP/World Bank/WHO Publication no 62 ;June 2000: 11 .

30. Abednego HM. Introduction. Guide for elimination of elephantiasis in Indonesia. Ministry of Health R.I Jakarta 1999 : i - ii

31. Molyneux DH. World-wide elimination of lymphatic filariasis. Bulletin of Tropical Medicine and International Health.2000;8(2):4. 